\title{
Kontribusi Syaikh Abdus Shamad Al-Palimbani pada Aspek Intelektual Islam di Nusantara Abad ke-18
}

\author{
Arafah Pramasto \\ Dinas Sosial Kota Palembang \\ Jl. Merdeka No.26, 22 Ilir, Kec. Bukit Kecil, Kota Palembang, Sumatera Selatan \\ arafahanakmadura@gmail.com
}

\begin{abstract}
Contributions of Shaykh Abdus Shamad Al-Palimbani to the Intellectual Aspects of Islam in the 18th Century Archipelago. Sheikh Abdus Shamad Al-Palimbani was sufi ulema from Palembang who had popularity, especially in writings, seminars, and public events in Sufism studies. This article attempts to reveal some backgrounds of Sheikh Abdus Shamad who's considered as a "go international ulema" such as from genetic aspect in which there are disputes about his 'kunya' (paternal lineage), pedagogy experiences and his works. By implementing library research within descriptive-analysis explanation, this writing testifies that Abdus Shamad was born in 1737 $\mathrm{AD}$, his grandfather, who was also a sufi ulema held a position of a mufti in Kingdom of Kedah. His grandmother, however, belonged to a noble family from Sultanate of Palembang. Abdus Shamad received good education during his lifetime in Palembang. He later continued his journey of knowledge-seeking by traveling to the Haramayn (holy lands of Islam) where he learned various Islamic principles. He also engaged in various discussions with ulemas and Malay speaking diciples also called the Jawi Community. As an Ulema and an intellectual, Sheikh Abdus Shamad authored eight books mostly in the Malay language.Two magnum opus of his writings that gained popularity among Indonesian Muslims were Sufi-themed books i.e. Hidayatus Salikin fi Suluk Maslak al- Muttaqiin and Siyarus Salikin ila Ibadat Rabb al-'alamin.
\end{abstract}

Keywords : Intellectual, Ulema, Indonesian Archipelago, Shaikh Abdus Shamad AlPalimbani

Abstrak: Kontribusi Syaikh Abdus Shamad Al-Palimbani pada Aspek Intelektual Islam di Nusantara Abad ke-18. Syaikh Abdus Shamad Al-Palimbani adalah ulama sufi asal Palembang yang populer dikaji dalam banyak tulisan, seminar, dan perhelatan publik untuk tema Sufisme. Tulisan ini berusaha mengungkap beberapa latar belakang Syaikh Abdus Shamad yang disebut sebagai "Ulama Go Internasional" yakni dalam masalah silsilah yang mana masih terdapat perbedaan mengenai

'kunyah' (nasab ayah) beliau, pengalaman pendidikan, dan karya-karyanya. Melalui penelitian kepustakaan dengan penjelasan analisis deskriptif, riset ini membuktikan bahwa Abdus Shamad dilahirkan pada 1737 M, kakeknya adalah seorang Ulama Sufi yang menjabat sebagai Mufti di Kerajaan Kedah. Latar belakang keluarganya itu memberi andil bagi Abdus Shamad untuk memperoleh pendidikan yang baik selama di Palembang. Ia kemudian melanjutkan pendidikannya ke Haramayn (Tanah Suci) untuk belajar ilmu-ilmu agama kepada pada Ulama serta aktif terlibat diskusi keilmuan di dalam "Komunitas Jawi”, yakni orang-orang Nusantara berbahasa Melayu yang belajar di sana. Sebagai seorang ulama sekaligus intelektual, Syaikh Abdus Shamad juga menghasilkan delapan buah karya yang sebagian besar berbahasa Melayu. Karyanya yang paling terkenal bagi Muslim di Nusantara adalah kitab Sufi berjudul Hidayatus Salikin fi Suluk Maslak al- Muttaqiin dan Siyarus Salikin ila Ibadat Rabb al-'alamin.

Kata Kunci : Intelektual, Ulama, Nusantara, Syaikh Abdus Shamad Al-Palimbani 


\section{Pendahuluan}

Harian Sumatera Ekspress memberitakan pada bulan Agustus 2016 silam mengenai acara napak tilas kesejarahan Syaikh Abdus Shamad Al- Palimbani, seorang ulama Sufi yang lahir di Palembang. Mal An Abdullah merupakan akademisi yang mempunyai spesialisasi dalam sejarah pemikiran Syaikh Abdus Shamad Al-Palimbani, beliau pun menjadi pembimbing dalam kegiatan napak tilas tersebut. Dalam kegiatan itu, para peserta juga akan mengunjungi Museum Kuala Kedah yang memuat informasi mengenai salah seorang penguasa Keddah yang bernama Sultan Muhammad Jiwa, yang mana dahulunya pernah belajar di Palembang.

Syaikh Abdus Shamad mempunyai seorang kakek yang diangkat sebagai Mufti di Keddah. "Beliau (Syaikh Abdus Shamad) punya kontribusi besar dalam perkembangan Islam di Nusantara dan beberapa daerah lainnya, terutama di tanah Melayu," demikian yang dijelaskan oleh Mal An Abdullah. ${ }^{1}$

Nama Abdus Shamad Al-Palimbani memang telah begitu populer dalam bidang kajian sejarah sufisme di Nusantara. Salah satu contoh dari popularitas tersebut diungkapkan oleh Martin Van Bruinessen, seorang antropolog dan orientalis asal Belanda yang mencurahkan perhatian pada sejarah penyebaran Islam di Indonesia. Bagi Bruinessen, Syaikh Abdus Shamad Al- Palimbani barangkali merupakan ulama paling terpelajar di sepanjang sejarah Nusantara. ${ }^{2}$ Kenyataan tersebut membuat ketokohan tentangnya menjadi jamak dikaji dalam bidang penulisan. Buku berjudul Ulama Sumatera Selatan contohnya, yang ditulis oleh Zulkifli sekira sembilan tahun setelah terbitnya kajian Bruinessen di atas, menuliskan bahwa pemikiran keagamaan ulama Sumatera Selatan abad ke-19 M dan awal abad ke-20 merupakan kontinyuitas dari pemikiran keagamaan ulama Sumatera Selatan sebelum- nya, dari segi kualitas karya-karya tersebut tidak sepopuler karya-karya Syaikh Abdus Shamad Al- Palimbani. ${ }^{3}$ Demikian pula dalam buku 101 Ulama Sumsel: Riwayat Hidup \& Perjuangannya tulisan Kemas H. Andi Syarifuddin (pemerhati manuskrip Palembang kenamaan) dan $\mathrm{H}$. Hendra Zainuddin, yang terbit atas kerjasama Forum Pondok Pesantren Sumatera Selatan dan Penerbit Ar-Ruzz Media (Yogyakarta), karya itu menyebut bahwa Syaikh Abdus Shamad ialah salah satu ulama besar dan penulis yang kaliber international. ${ }^{4}$

Kajian mengenai Syaikh Abdus Shamad masih terus giat diulas bahkan hingga ke tahun 2019. Tidak hanya dalam ranah penulisan saja, ketokohan Syaikh Abdus Shamad turut diungkap dalam dua perhelatan yang diselenggarakan di kota Palembang. Acara Pekan Pustaka Palembang yang dilaksanakan pada tanggal 21 hingga 28 April 2019 ditujukan untuk menjadi ajang berbagi pengetahuan perihal beragam bahan bacaan mengenai Kota Palembang, mengambil tempat di Perpustakaan Masjid Agung Palembang (Lantai 3). Dalam buklet yang dibagikan oleh pihak panitia menyebut nama Syaikh Abdus Shamad Al-Palimbani sebagai salah seorang ulama Palembang yang "termasyhur produktif." 5 Selepas Pekan Pustaka Palembang usai, tanggal 18 Juli 2019 dihelat Seminar Sehari bertema "Mengenal Lebih DekatSejarah Perjuangan Pendiri Masjid Agung Palembang dan Ulama Pencetak Al-Quran Pertama di Asia Tenggara" oleh Yayasan Masjid Agung Palembang. Meski pun dalam seminar itu berkonsentrasi dalam memaparkan peran Sultan Mahmud Badaruddin Jayo Wikramo sebagai pendiri Masjid Agung Palembang, Kemas H. Andi Syarifuddin selaku pemateri turut menyebut bahwa masjid tersebut memiliki fungsi sebagai "Pusat Kajian Sastra Melayu" yang melahirkan para ulama 
besar sekaligus penulis, dan nama pertama yang disebut adalah, “...Syekh Abdus Somad al- Palembani..." 6

Penulisan artikel ini bertujuan untuk mengungkap latar belakang Syaikh Abdus Shamad, sebagaimana di atas telah didapati ulasan-ulasan yang menunjukkan popularitasnya sebagai objek kajian dalam lingkup penulisan maupun perhelatan- perhelatan ilmiah. Setelah melalui proses tindakan penelusuran kepustakaan atau kadang disebut studi pustaka, yakni serangkaian kegiatan yang berkenaan dengan metode pengumpulan data pustaka, membaca, mencatat serta mengolah bahan penelitian, ${ }^{7}$ penulis menemukan tiga pokok kajian utama yang perlu dibahas secara komprehensif yakni rekonstruksi silsilah atau nasab beliau, kemudian pola empirik bidang pedagogi yang dialami oleh Syaikh Abdus Shamad, serta karir intelektual beserta kontribusi pemikirannya.

\section{Pembahasan}

\section{A. Rekonstruksi Silsilah Syaikh Abdus Shamad}

Ulama asal Palembang ini diyakini bernama lengkap Abdus Shamad bin Abdul Jalil Al-Jawi Al-Palimbani. Tetapi sumber-sumber Arab menyebutnya dengan Sayyid Abdus Shamad bin Abdurrahman Al-Jawi. ${ }^{8}$ Menurut Tarikh Salasilah Negeri Kedah, Syaikh Abdus Shamad dilahirkan sekitar 1116 H / 1704.

M. Dalam kajian yang populer ditemukan tentang silsilah beliau, dikatakan bahwa ayahnya adalah Abdul Jalil bin Abdul Wahab bin Ahmad Al-Madani, seorang ulama sufi di San'a (Yaman) dan pernah menjabat sebagai mufti besar di Kerajaan Kedah, tetapi kemudian menikah dengan wanita Palembang, Raden Ranti. ${ }^{9}$ Sebelum itu, ayah Abdus Shamad pernah melakukan perjalanan ke India dan Jawa, kemu- dian menetap di Palembang lalu menikahi saudari perempuan Sultan Mahmud Badaruddin I tersebut. ${ }^{10}$

Ayahnya sempat menjabat sebagai kepala penjaga Istana Kuto Cerancangan pada masa Sultan Mahmud Badaruddin I. ${ }^{11}$

Selain tanggal lahir yang tidak bisa ditentukan secara pasti, didapatkan juga beberapa perbedaan nama kunyah (ayah) dari Al-Palimbani, keterangan dari Tarikh Salasilah Negeri Kedah masih terlalu sering diambil sebagai sumber utama dalam menjelaskan silsilah Syaikh Abdus Shamad. Perbedaan nama kunyah ini merupakan hal yang cukup krusial dalam pengkajian riwayat Syaikh Abdus Shamad.

Dalam perkembangan selanjutnya, perbedaan nama kunyah dari Syaikh Abdus Shamad itu sebenarnya perlu dibenahi lagi. Salah satu ahli dalam bidang kajian ini ialah Mal An Abdullah seorang akademisi UIN Raden Fatah Palembang, ia berhasil meluruskan kerancuan yang ada seputar silsilah Syaikh Abdus Shamad dalam penelitian terbarunya. Dalam artikel yang ia tulis dalam surat kabar Sumatera Ekspres, Mal An menerangkan bahwa untuk waktu yang lama, informasi yang sampai kepada umum tentang waktu lahir dan ayah Syaikh Abdus Shamad semata berdasarkan perkiraan. Ternyata informasi tersebut keliru. Untunglah di Palembang ada manuskrip tentang manaqib-nya yang berjudul Faydh Al-Ihsani, yang sekarang dikoleksi oleh Kemas H. Andi Syarifuddin. Berdasarkan manaqib itu dapat dipastikan bahwa Syaikh Abdus Shamad dilahirkan di Palembang pada tahun $1150 \mathrm{H}$ atau 1737 M. Ayahnya bernama Abdur Rahman. Ditilik dari sumber lain, Abdur Rahman ternyata anak Syaikh Abdul Jalil bin Abdul Wahab bin Ahmad Al-Mahdali, mufti Ke- 
sultanan Keddah. Ibu Abdur Rahman tercatat bernama Raden Ranti, anak perempuan dari Pangeran Purbaya, yang tidak lain adalah putra tertua dari Muhammad Mansur, Sultan Palembang yang memerintah pada 1706-1714. Dengan demikian, dari jalur nenek perempuannya, Syaikh Abdus Shamad adalah bagian dari kerabat utama Keraton Palembang yang garis nasabnya terhubung lurus dengan Sultan. ${ }^{12}$

Lebih lanjut, Mal An menjelaskan sumber lain yang menerangkan tentang siapa sesungguhnya Raden Ranti yang dinikahi oleh Abdul Jalil terdapat dalam sebuah manuskrip yang ditulis pada tahun 1867 bertajuk Silsilah Anak-Anak Bangsawan Palembang yang mencatat bahwa Raden Ranti sebagai anak ke-15 (terakhir) dari Pangeran Purbaya. ${ }^{13}$ Guna memperjelas isi dari manuskrip Faydh Al- Insan tentang kejelasan ayah Syaikh Abdus Shamad, dapat dilihat dari kutipan yang diambil oleh Mal An Abdullah berikut ini, ${ }^{14}$ ".... yaitu Syaikh Abdus Shamad yang anak Abdur Rahman...” (h. 5) “...yaitu penghulu kita Syaikh Abdus Shamad yang anak Abdur Rahman Al-Jawi Palimbani negerinya...." (h. 11)

Berdasarkan Manuskrip Faydh Al- Insan - menurut penelusuran Kemas Andi Syarifuddin - Nyayu Halimah adalah perempuan yang membuat salinan naskah tersebut, yaitu salah satu keturunan Syaikh Abdus Shamad dari generasi ketiga yang bermukim di Palembang, yang berasal dari jalur pernikahannya dengan Aisyah binti Idrus dari Aden. Kemas Andi Syarifuddin mendapatkan naskah ini dari salah seorang anak Nyayu Halimah. Melihat catatan pada sampulnya, dapat diperkirakan bahwa penyalinan naskah oleh Nyayu Halimah dalam rangka haul (peringatan kematian) Syaikh Abdus Shamad. Jika dihitung menurut kalender Hijriyah, tarikh penyalinannya dimulai dari 24 Dzulqaidah sampai 21 Dzulhijjah 1355 H. Tarikh ini sejalan dengan manuskrip Zikir Syeikh Muhammad Al-Samman, koleksi Perpustakaan Negara Malaysia (PNM), MSS 2367, yang mencatat jadwal haul Syaikh Abdus Shamad ialah, "pada malam yang ketujuh belas dari pada bulan Dzulqaidah". ${ }^{15}$

Abdul Jalil selaku kakek dari Syaikh Abdus Shamad adalah seorang ulama yang beraliran Sufi dan berasal dari Yaman, sebagaimana dijelaskan sebelumnya. Penjelasan mengenai dirinya begitu penting mengingat perlunya kelengkapan dalam merekonstruksi silsilah dari Syaikh Abdus Shamad. Pada sekitar abad ke 17 dan 18, Kesultanan Palembang Darussalam mencapai masa puncak keemasannya, menjadi salah satu dari empat pusat pengkajian Islam terbesar di Nusantara setelah Aceh mengalami kemunduran pada akhir abad ke 17, dan Palembang mengambil alih status "Islamic Centre" (Pusat Keislaman) di sekitar tahun 1750-1820, dan seterusnya masing-masing beralih ke Banjarmasin dan Padang. ${ }^{16}$ Sependapat mengenai hal itu, Husni Rahim juga menerangkan setelah kemunduran Aceh, muncul Palembang sebagai pusat studi Islam dan sastra. Kebiasaan memelihara "Ulama Keraton" telah dirintis sejak zaman Sultan Mahmud Badaruddin I (1724-1757 M)..$^{17}$

Jelasnya hal tersebut bukanlah sebuah kecenderungan pertama, karena Palembang telah menjadi enclave penting bagi Islam sejak abad ke-16, sebagaimana dicatatkan oleh Tome Pires dalam Suma Oriental-nya. ${ }^{18}$

Abdul Jalil datang ke Palembang pada awal abad ke-18. Dikisahkan bahwa setelah Tengku Muhammad Jiwa berada di Palembang selama enam bulan, Abdul Jalil kemudian berlayar ke Jawa. Tengku Muhammad Jiwa adalah seorang anak Sultan Kedah, 
karena merasa mantap akan pelajaran yang diterimanya dari Abdul Jalil itu maka merasa sedihlah ia berpisah dengan ulama tersebut, sehingga keberangkatan Abdul Jalil ke Jawa pun diikutinya. Dari Jawa, Abdul Jalil berangkat ke India dan Tengku Muhammad Jiwa terus mengikutinya. Abdul Jalil tidak mengetahui bahwa muridnya itu adalah seorang anak raja. Banyak negeri yang dikunjungi di India, barangkali sebelumnya Abdul Jalil adalah penyebar Islam disana dan memiliki banyak murid. Salah seorang di antara muridnya yang berilmu adalah "Hapisap" (mungkin nama aslinya "Hafiz Sab"). Terjalinlah persahabatan antara Tengku Muhammad Jiwa dan Hapisap yang berkebangsaan India itu, keduanya bersama mengikuti dan mematuhi fatwa dari gurunya yang mereka panggil "Syaikh" Abdul Jalil. Sekian lama meninggalkan negerinya, Tengku Muhammad Jiwa meminta kesediaan gurunya untuk mengikutinya ke Keddah. Dengan menumpang kapal layar kepunyaan orang "Maskat" (kemungkinan besar adalah "Muskat" di Oman) berangkatlah ketiganya dari India, setelah banyak singgah akhirnya mereka sampai di Murqui, daerah selatan Burma. Dalam suatu kesempatan yang tak disangka-sangka, Kedah mengirim utusan bernama Dato' Seri Indera Mambang Senggara untuk mencari Muhammad Jiwa, kapalnya berlabuh di sebelah kapal yang ditumpangi oleh Muhammad Jiwa. Disana ia bertemu dengan putera rajanya tersebut, Muhammad Jiwa merasa senang dengan pertemuannya dengan Dato' Seri Indera Mambang Senggara, tapi saat itu juga ia mendengar bahwa ayahnya yakni Sultan Abdullah dan adiknya (saudara Muham- mad Jiwa), Dato' Seri Paduka Maharaja Sultan Ahmad Tajuddin sebagai pengganti Sultan Abdullah, keduanya telah wafat. Berita itu membuat Muhammad Jiwa menangis, di saat itulah Abdul Jalil mengetahui bahwa muridnya adalah seorang putra Sultan Kedah. ${ }^{19}$

Setibanya di Keddah, Muhammad Jiwa segera dinobatkan sebagai Sultan (disebut Sultan Zainal Abidin Muazzam Shah II, memerintah sampai 1778), ia juga mengangkat gurunya sebagai Mufti dan Hapisap sebagai Qadhi. Ia juga menjodohkan Abdul Jalil dengan seorang keluarga istana bernama Wan Zainab. Beberapa bulan setelah pernikahan itu, Abdul Jalil didatangi oleh Raden Siran, salah seorang muridnya semasa di Palembang yang memintanya berkenan mengunjungi muridmuridnya di sana. Abdul Jalil lalu pergi ke Palembang untuk kali yang kedua. Ia diminta mengajar dan kemudian dijodohkan dengan Raden Ranti dan dari situ ia memperoleh anak bernama Abdur Rahman, ayah Syaikh Abdus Shamad yang secara keliru ditulis Abdul Jalil dalam Tarikh Salasilah Negeri Keddah. ${ }^{20}$ Dari kisah ini kita harus memperhatikan beberapa hal yakni bahwa Abdul Jalil merupakan tipe ulama pemukim sementara, besar kemungkinan juga ia adalah tipe sufi pengelana namun menguasai ilmu syariat (fiqh) sehingga ia dianggap layak oleh Muhammad Jiwa untuk mendapatkan posisi Mufti. Hubungan regional dan keilmuan di dunia Melayu Islam amat mencolok saat Raden Siran, salah satu murid Abdul Jalil yang memintanya kembali mengajar di Palembang, berarti pada masa itu para pencari ilmu telah sangat pro-aktif dalam mencari guru ini tidaklah mungkin dapat terwujud tanpa adanya dukungan dari pemerintahan Kesultanan Palembang. 


\section{B. Pendidikan Syaikh Abdus Shamad}

Di tengah kemajuan dunia keilmuan Palembang itu, Abdur Rahman memiliki seorang putra yang ia beri nama Abdus Shamad. Hidup sebagai keturunan bangsawan, masa kecil Syaikh Abdus Shamad tidaklah mudah. Menurut Faydh Al-Insani ia tidak lama merasakan asuhan ibunya yang harus meninggalkan ia selamanya : "dan adalah dahulu daripada sampai umurnya setahun maka lalu ibunya ke rahmat Allah Ta'ala, maka jadi ia yatim dalam rahmat mudanya...." Dalam penelusuran Mal An Abdullah, diketahui bahwa istri Abdur Rahman adalah Masayu Syarifah, dari namanya menunjukkan bahwa wanita itu berasal dari keluarga bangsawan. Selanjutnya, dalam manuskrip yang sama, Syaikh Abdus Shamad kecil juga harus hidup tidak dibesarkan oleh ayahnya : “...tatkala sampai umurnya kira-kira sembilan tahun berpindah bapanya kepada "Negeri yang Sejahtera"..... Tidak disebutkan kemana ayahnya pergi. Sangat mungkin "Negeri yang Sejahtera" merujuk kepada terjemahan dari "Dar Al- Aman", kemungkinan yang amat besar adalah "Keddah Dar AlAman", kakek Abdus Shamad masih menjadi Mufti di tempat itu hingga tahun 1782. Syaikh Abdus Shamad yang dibesarkan di lingkungan Keraton Kuto Cerancangan membuatnya mendapatkan banyak pengajaran dari para ulama Palembang seperti Tuan Faqih Jalaluddin, Hasanuddin bin Jakfar, dan Sayyid Hasan bin Umar Idrus merupakan sederet nama ulama yang pernah memberi pengajaran pada beliau. Melalui bimbingan Sayyid Hasan bin Umar Idrus, Syaikh Abdus Shamad mempelajari Al-Quran dan tajwidnya serta berhasil menghafalnya pada usia 10 tahun. ${ }^{21}$

Tentang Sayyid Hasan bin Umar Idrus, Syaikh Abdus Shamad mengenangnya dengan baik, dalam Faydh Al-Insani ; “....... melazimkan ia bagi rumah Imam yang mempunyai ma'rifat pada pengetahuan akan Allah Ta'ala, yaitu yang menarikkan akan kita, Sayyid Hasan yang anak Sayyid Umar Idrus, yang pilihan daripada anak cucu Nabi segala anak 'Adnan, kerana menunutut ilmu dan memaham dalam agama dan membaikkan tajwid membaca Quran." Sayyid Hasan memperhatikan, mengawasi dan berupaya membentuk pola tingkah keseharian Syaikh Abdus Shamad, "maka menilik akan dia dengan tilik peliharaan dan bersungguh-sungguh ia dengan membaikkan kelakuannya itu...." Abdus Shamad tidak menghabiskan masa kecilnya dengan bermain-main, tapi tiada pula ia merasa menyesal menghabiskan waktu dengan menuntut ilmu, hingga harta peninggalan ayah-ibunya yang berupa ; "dua peti daripada pakaian perak dan kain sutera baik-baik," harus habis, "maka hilang binasa keduanya itu dahulu daripada aku 'aqil baligh," ia sama sekali tidak menyesalinya ; "maka tiada aku berpaling pada keduanya....aku ketahui bahwa Allah Ta'ala menjadikan ia akan daku mengikut dengan penghulu tempat kita berpegang, yaitu nabi Muhammad Saw." Pribadi Syaikh Abdus Shamad bisa dibilang sangat "haus ilmu", karena selain belajar ilmu keagamaan, ia masih juga menyempatkan waktu untuk belajar seni silat Palembang. Kakeknya dari nasab Palembang, Pangeran Purbaya amat termasyhur sebagai "ahli pendidik ilmu silat dan urusan peperangan". ${ }^{22}$

Diperkirakan pada usia baligh awal, sebelum 1750, Syaikh Abdus Shamad berangkat ke Mekkah untuk melanjutkan pendidikan. Kehidupan intelektual Palembang kala itu terlihat begitu maju, bahkan sosok seperti Syaikh Abdus Shamad juga mewakili masyarakat pribumi yang proaktif dalam meningkatkan kemampuan in- 
telektual di bidang agama. Di sisi lain kita dapatkan pula tentang orientasi keilmuan Islam yang nampak di Palembang. Literatur keagamaan setempat di wilayah ini pada akhir abad ke-18 dan permulaan abad ke-19 tidak mencakup karya-karya Hamzah Fansuri dan Syamsuddin As-Sumatrani, ataupun tulisan-tulisan lain yang dianggap menyimpang (unorthodox) atau dianggap ajaran sesat (heterodox). Sebaliknya karya-karya Nuruddin Al- Raniri, dan Abdur Rauf Al-Sinkili beredar luas. Nampaknya ulama-ulama Palembang menolak untuk mengkaji kitab-kitab yang dianggap bermasalah. ${ }^{23}$

Kepedulian para Sultan yang hendak menjadikan Palembang sebagai pusat ilmu keagamaan membuat Palembang memiliki banyak koleksi naskah-naskah karya ulama setempat dan salinan dari kitabkitab yang ditulis oleh ulama Timur Tengah. Dua Sejarawan seperti G.W.J. Drewes dan T. Iskandar memberikan daftar naskah-naskah yang dikoleksi oleh Keraton Palembang pada abad ke-18, di antaranya ialah :

a. Idrak Al-Haqiqah fi Takhrij Ahadits Al-Thariqah karya Ali Ibn Hasan Ibn Sadaqa Al-Mishri.

b. Kitab Al-Hikam karya Ibn Ath-Thailah yang diterjemah ke dalam bahasa Melayu sebagai koleksi Sultan Ahmad Najmuddin.

c. Asrar Al-Arifin karya Nuruddin ArRaniri.

d. Umdat Al-Muhtajin dan Daqa'iq AlHuruf karya Abdur Rauf Al-Sinkili.

e. Serat Wulang Jayalengkara yang menjadi koleksi pribadi Sultan Baha' uddin;

f. Jawharat At-Tauhid karya Ibrahim AlLaqani yang diterjemahkan oleh Shihabuddin bin Abdullah Muhammad.

g. Risalah fii At-Tauhid karya Syaikh Raslan Al-Dimasqi. h. Futuh Al-Syam karya Abu Isma'il Al- Bashri.

i. Thufah Al-Zaman fi Zharf Ahl Al-Yaman karya Saddad Himyari. ${ }^{24}$

Untuk masalah Tasawuf, ia memilih Tarekat Samaniyyah melalui pengajaran dari Syaikh Muhammad bin Abd AlKarim Al-Samani Al-Madani. Guru-guru Syaikh Abdus Shamad lainnya selama ia belajar di Timur Tengah antara lain Syaikh Muhammad bin Sulaiman Al-Kurdi, Syaikh 'Abd Al-Mun'im Al-Damanhuri, Syaikh Ibrahim Al-Ra'is Al-Zamzami, Syaikh Muhammad bin Jawhari Al-Mishri serta Syaikh Ath-Tha'ilah Al-Azhari AlMishri. ${ }^{25}$ Disana ia belajar bersungguhsungguh sekitar kurang lebih 20 tahun.

Di samping kesibukannya dalam menuntut ilmu dengan berguru kepada pada Ulama, Syaikh Abdus Shamad pun tidak melalaikan aktifitas lainnya yang masih berhubungan dengan bidang keilmuan namun secara khusus ialah dalam hal membina hubungan maupun diskusi keilmuan di dalam sebuah kelompok yang disebut "Komunitas Jawi." Kata / sebutan "Jawi" merujuk kepada orang-orang berbahasa Melayu yang ada di Haramayn (Mekkah dan Madinah). Jaringan keilmuan komunitas Jawi yang berbahasa Melayu ini tumbuh akibat maraknya jamaah Nusantara yang beribadah haji serta berkesempatan mendalami ilmu agama melalui pengajian-pengajian berbahasa Melayu di berbagai tempat di kedua kota suci tersebut, hal ini tidak mengherankan telah mengakibatkan bahasa Melayu sejak 1860 menjadi bahasa kedua di Mekkah sesudah bahasa Arab. ${ }^{26}$

Peran strategis Komunitas Jawi dalam bidang keilmuan Islam di Nusantara sejatinya telah terjadi sejak seabad sebelum kelahiranSyaikh Abdus Shamad. Kelompok ini telah membina kehidupan intelektual yang terbilang 
interaktif dengan ulama-ulama yang hidup di Haramayn. Dalam komunitas inilah, kemungkinan besar Syaikh Abdur Rauf As-Sinkili mempertanyakan bagaimana seyog-yanya kitab Al-Thufah Al- Mursalah ${ }^{27}$ karangan Fadlallah Al-Hindi Al-Burhanpuri dengan isu utamanya adalah kontroversi seputar penerimaan kasyaf (pencerahan illahi) yang dianggap membolehkan seseorang untuk meninggalkan kewajiban syariat. Pendapat itu kemudian dibantah oleh Ibrahim Al-Kurani dalam sebuah kitab yang berjudul Ithaf Al-Dhaki sebagai sebuah komentar untuk karya Burhanpuri yang ditulis atas permintaan komunitas Jawi. Kurani memakai hujjah (bukti) yang terbantahkan bahwa Rasulullah sendiri telah menerima kasyaf tertinggi pada waktu Mi'raj $^{28}$ - sebagai sebuah sebab awal turunnya syariat shalat. Abdul Rauf Al-Sinkili adalah murid dari Ahmad Al- Qushashi, Khalifah tarekat Syattariyah di Madinah sebelum akhirnya digantikan oleh Ibrahim AlKurani setelah Al- Qushashi wafat.

Apabila kita menyebutkan nama Syaikh Abdus Shamad dalam lingkungan Ulama Jawi, tentunya tak dapat dilepaskan dengan empat nama lain yang dipercaya berangkat ke Haramayn dan Timur Tengah untuk belajar bersama yakni Syaikh Muhammad Arsyad Al- Banjari, Syaikh Abdul Wahab Al-Bugisi, Syaikh Abdurrahman Al-Jawi Al-Batawi Al-Mishri dan Syaikh Daud Al-Fathani. Akan tetapi Mal An Abdullah memberikan koreksi bahwa Syaikh Muhammad Arsyad dan Syaikh Abdul Wahab lebih tua umurnya daripada Syaikh Abdus Shamad, bahkan Syaikh Muhammad Arsyad terlebih dahulu tiba di Makkah. ${ }^{29}$ Syaikh Daud Al-Fathani justru baru tiba di Mekkah pada akhir

1780-an dan berguru kepada Syaikh Abdus Shamad saat Syaikh Abdus Shamad telah menjadi ulama di komunitas Jawi yang terkemuka. ${ }^{30}$
Syaikh Abdurrahman Al-Jawi Al- Batawi Al-Mishri kemungkinan besar yang seusia dengan Syaikh Abdus Shamad, walau bagaimanapun bersama Syaikh $\mathrm{Mu}-$ hammad Arsyad dan Syaikh Abdul Wahab, Syaikh Abdurrahman menjadi teman dekat dari Syaikh Abdus Shamad. Ada Sebuah kisah menarik dari keempat orang ulama Nusantara yang berguru kepada seorang ulama - telah disebutkan di atas - yang bernama Syaikh Ath-Tha'ilah AlAzhari Al-Mishri, saat mereka meminta izin untuk menimbailmu ke negeri Mesir, sang guru memberi nasihat lain ; mengejar ilmu memang sangat penting, namun mengajarkan ilmu adalah hal yang juga tidak bisa ditinggalkan. Syaikh Ath-Tha'ilah Al- Azhari Al-Mishri meminta mereka untuk kembali ke tanah air dan mengajarkan Islam serta berdakwah di tempat masing- masing. ${ }^{31}$ Setelah mendapat nasihat ini Syaikh Abdus Shamad bersama ketiga teman dekatnya itu kembali ke Nusantara, sebenarnya inilah kepulangan pertama Syaikh Abdus Shamad yang pertama ke Palembang, ketiganya berpisah di Betawi sebelum menuju tempat masing-masing. ${ }^{32}$

Pesan yang diberikan oleh gurunya itu nampak memberi sebuah makna yang mendalam bagi Syaikh Abdus Shamad, betapapun ketenaran yang didapatkan olehnya di Haramayn, ia tidak melupakan kewajibannya untuk menyebarkan pengetahuan yang diperoleh kepada masyarakat Nusantara. Di tanah Arab ia amat menggemari pelajaran Tauhid dan Tasawuf. Ia juga sangat terpengaruh oleh pemikiran Imam Al-Ghazali dan sangat mahir dalam kajian kitab Ihya' Ulumuddin. Sedangkan dalam konteks Tarekat Sammaniyah di Palembang, beliau diakui sebagai salah satu guru dalam silsilah Tarekat tersebut. Hal ini menunjukkan perannya dalam penyebaran ajaran Sammaniyah ke $\mathrm{Nu}$ - 
santara yakni di Kesultanan Palembang. Seorang Ulama Tasawuf yang juga mengikuti Tarekat Sammaniyah asal Palembang, yang berusia lebih muda dari Syaikh Abdus Shamad, yakni Syaikh Muhammad Azhari Al-Palimbani (lahir $1856 \mathrm{M}$ ), mencatatkan nama silsilah dari ajaran Sammaniyah di Palembang sebagai berikut, "Maka inilah silsilah tarekat Khalwatiyah As-Samaniyah. Yakni turun tempat mengambil dzikir dan kaifiyat bagi Waliyullah yang terlebih takut akan Allah ta'ala, yaitu Quthb Al-Rabbani dan 'Arif yang Samadani, yaitu guru-guru kita dan penghulu kita yaitu Asy-Syaikh Muhammad bin Asy-Syaikh Abdul Karim As-Saman Al-Madani yang telah mahsyur. Dan sungguhnya telah mengambil talqin dzikir ini oleh faqir :

- Muhammad Azhari Ibn Abdullah AlPalimbani, ia mengambil daripada

- Asy-Syaikh Abdullah bin Ma'ruf AlPalimbani, ia mengambil daripada

- Asy-Syaikh Muhammad Aqib bin Hasanuddin Al-Palimbani, ia mengambil daripada

- Asy-Syaikh Abdus Shamad Al-Palimbani, ia mengambil daripada

- Quthb Al-Akwan Sayyidina Muhammad As-Samani Al-Madani....." 33

\section{Karya-karya Syaikh Abdus Shamad Al-Palimbani}

Syaikh Abdus Shamad Al-Palimbani dikenal sebagai ulama yang memiliki hasil-hasil karya pemikiran berupa kitabkitab dalam jumlah yang begitu banyak. Subjek kajiannya terutama ialah bidang Tasawuf. Di samping itu, Syaikh Abdus Shamad juga mengkaji mengenai persoalan Tauhid dan pentingnya membela negara. Ia memiliki kemampuan yang baik dalam bahasa Arab, namun tidak melupakan tanah kelahirannya, hal ini ditunjukkan dengan penulisan karyanya yang juga menggunakan bahasa Melayu. Sejarawan seperti Drewes mengungkapkan bahwa Syaikh Abdus Shamad memiliki tujuh buah kitab yang terkenal, ${ }^{34}$ Cuzwain dan Azyumardi Azra menambahkan satu lagi kitabnya yang terkenal yaitu Thuhfah Al-Raghibin,, ${ }^{35}$ sehingga menjadi delapan buah. Secara lengkap rinciannya adalah sebagai berikut:

a) Hidayatus Salikin fi Suluk Maslak al-Muttaqiin ditulis pada 1778 M. Kitab ini berbahasa Melayu. Kitab ini bukan saja terjemahan dari Bidayat Al-Hidayah Imam Al-Ghazali, namun juga dilengkapi dengan komentar yang ditulis oleh Syaikh Abdus Shamad. Secara khusus akan dikaji pada sub-bab selanjutnya.

b) Siyarus Salikin ila Ibadat rabb al'alamin yang ditulis pada 1779 M. Kitab ini berbahasa Melayu yang diterjemahkan dari kitab Imam Al-Ghazali, Ihya' Ulumuddin. Namun, seperti Kitab Hidayat al- Salikin, ia tidak hanya menerjemahkannya saja, ia juga memberikan wacana-wacana lain dalam kitab tersebut dan memberi warna baru. Dalam kitab ini ia berusaha mengkompromikan pemikiran-pemikiran "Sufisme Lama" dari para tokoh seperti Ibn 'Arabi, Al- Jilli, dan Burhanpuri, namun ditafsirkan dalam pemikiran Imam AlGhazali dan membentuk corak pemikiran Neo-Sufisme.

c) Thufah Al-Raghibin fi Bayan Haqiqat Iman Al-Mu'minin, kitab ini berbahasa Arab dan ditulis pada $1774 \mathrm{M}$. Berisi tentang peringatan-peringatan mengenai paham-paham yang menyebar dan memungkinkan untuk menyesatkan umat. Menurut Drewes, kitab ini ditulis menurut permintaan Sultan Baha'uddin yang memerintah di Palembang. 
d) Nasihat al-Muslimin wa Tadzkirat alMu'minin fi Fadha'il Al-Jihad fi Sabilillah wa Karamat al-Mujahidin fi Sabilillah, kitab ini ditulis dengan berbahasa Arab dan berisi tentang anjuran berjihad di jalan Allah (Jihad fi Sabilillah). Kitab ini juga merupakan jawaban atas penjajahan bangsa barat yang terjadi di Nusantara.

e) Zuhrat al-Murid fi Bayan Kalimat alTawhid, diperkirakan ditulis pada 1764 $\mathrm{M}$ dengan bahasa Melayu yang berisi tentang kajian-kajian kalimat Tauhid.

f) Al-Urwat al-Wutsqa wa Silsilat Uli al-Ittiqa, ditulis dengan bahasa Arab yang berisi tentang wirid-wirid dan doa dalam waktu-waktu tertentu.

g) Ratib Abdus Shamad, satu-satunya buku yang ditulis berdasarkan nama dirinya, di dalamnya berisi doa-doa, dzikir, dan shalawat (Ratib) yang dilakukan setelah Shalat Isya' seperti yang sering ia lakukan. Kitab ini sebenarnya hampir sama dengan Ratib dari gurunya yaitu Syaikh Muhammad bin Abd Al-Karim Al-Samani Al-Madani dari Tarekat Sammaniyah.

h) Zadd Al-Muttaqin fi Tawhid Rabb al'Alamin, yang berisi ringkasan ajaran Tauhid yang di dapatkan dari gurunya, Syaikh Muhammad bin Abd Al-Karim Al-Samani Al-Madani.

Dapat disimpulkan bahwa kitab-kitab kajian yang ditulis oleh Syaikh Abdus Shamad memiliki keberagaman kajian, sekalipun ia dikenal sebagai seorang ahli dalam bidang Tasawuf / Sufisme. Berdasarkan karya-karyanya tersebut kita bisa melihat terdapat aspek perlawanan terhadap penjajahan, terutama dari kitab Nasihat al-Muslimin wa Tadzkirat al-Mu'minin fi Fadha'il Al-Jihad fi Sabilillah wa Karamat al-Mujahidin fi Sabilillah. Kemampuan kompleks dalam mengkaji banyak tema dalam konteks keagamaan sebagaimana yang terlihat dalam penulisannya itu telah menunjukkan aspek "kemodernan" berfikir yang dimiliki oleh Syakh Abdus Shamad Al-Palimbani.Kepeduliannya kepada fenomena yang terjadi masyarakat dapat dikategorikan sebagai bentuk Sufisme "Baru". Stereotip yang sering terdengar tentang Sufisme adalah asketisme individual yang menolak atau setidaknya meninggalkan segala hal tentang keduniawian untuk mendekatkan diri kepada Allah semata.Pesimisme terhadap dunia bukanlah hal yang diajarkan oleh Islam sekalipun agama ini memang mengatur keseimbangan dalam menyikapi dua dimensi yang menjadi realitas kehidupan Muslim di seluruh dunia.

Kitab Siyarus Shalikin dan Hidayatus Shalikin adalah dua kitab yang menjadi Magnum Opus dari karya- karyanya dan menunjukkan garis besar sifat pemikirannya. Al-Palimbani dalam Muqaddimah (Pembukaan) Kitab Hidayatus Shalikin-nya menyatakan bahwa kitabnya itu adalah ikhtisar dari kitab Imam Al- Ghazali Bidayatul Hidayah. Sebagai sebuah kitab yang mengkaji ilmu Tasawuf, Hidayatus Shalikin, yang terdiri atas satu Muqaddimah, tujuh bab, dan satu Khatimah (penutup). Apabila sejauh ini Tasawuf selalu diasosiasikan dengan tindakan yang bertentangan dengan ortodoksi Islam, Hidayatus Salikin sebagai kitab Tasawuf justru ditulis dengan sistematika yang dimulai dengan hal-hal mendasar (lahiriah). Seperti dalam Bab I: Aqidah yang membahas hakikat Tauhid, Bab II: Ketaatan yang banyak membahas masalah Thaharah (bersuci) dan Sholat, Bab III: Maksiat Dzahir/ Fisik, Bab IV: Maksiat Bathin, dan baru Bab V: Ketaatan Bathin. Sistematika itu mengisyaratkan bahwa sebelum mengkaji Bab $\mathrm{V}$ tentang ketaatan Bathin, Al- Palimbani mengajak 
pembaca untuk melewati empat tahapan perkara fisik (eksoterik) terlebih dahulu.

Tujuh bab dalam kitab Hidayatus Shalikin dimulai dari hal-hal mendasar yang kemudian berangsur-angsur mengkaji hal-hal yang lebih mistis. Seperti dalam Bab I: Aqidah, di dalamnya kembali dikaji mengenai pengetahuan atas ketauhidan atau keesaan Allah SWT. Bab II: Ketaatan. Dalam Bab III: Maksiat Dzahir. Bab IV: Maksiat Batin. Setelah itu di dalam Bab V: Ketaatan Batin, Syaikh Abdus Shamad mengkaji hal-hal yang bisa mencegah keburukan dari maksiat dzahir dan maksiat batin melalui beberapa ketaatan yang harus direnungkan dan diterapkan seperti taubat, khauf (takut pada Allah), zuhud (kecondongan kepada akhirat, sabar, syukur, ikhlas-Shiddiq, Tawakkal, Mahabbah (orientasi cinta pada Allah, ridha pada takdir (namun bukan berarti berakibat menyerah kepada kebathilan), dan ditutup dengan zikril mawt (selalu ingat akan kematian). Bab VI: Fadhilat, Kaifiat Dzikir, ialah bab yang menjelaskan tentang adab dzikir dan keutamaannya. Dimensi Sosial bermasyarkat dapat ditemukan dalam Bab VII: Adab hubungan pada Allah dan Pergaulan terhadap Manusia, yang isinya antara lain tentang adab seorang alim, adab pelajar, adab hubungan anak-orang tua, dan adab berteman, dan Khatimah: Adab Berkenalan, merupakan bagian yang cukup unik dari kitab ini karena di dalamnya mengkaji hubungan manusia dengan orang yang sekadar kenal, orang yang telah dekat sebagai sahabat, dan orang yang tidak saling kenal, dan bagaimana berhubungan dengan baik kepada semua jenis orang itu.

Musyrifah Sunanto dalam bukunya, Sejarah Peradaban Islam Indonesia menjelaskan bahwa kitab Hidayatus Shalikin ini membicarakan aturan-aturan syariat yang ditafsirkan secara mistis. Selain menambahkan beberapa topik dari kitab aslinya, Syaikh
Abdus Shamad juga mengutip kitab-kitab Al-Ghazali lainnya seperti Ihya' Ulumuddin, Minhajul 'Abidin ataupun Arba'in fi Ushuluddin, di samping melengkapinya dengan acuan dari tokoh- tokoh terkemuka seperti Yawaqit Al- Jawahir dari Al-Sya'roni, Durr Al-Tsamin dari Abdullah Al-Aydarus, Bustanul 'Arifin karya Al-Qusyaisyi, dan Nafhatul Ilahiyah karya Al-Samani. ${ }^{36} \mathrm{Hi}-$ dayatus Shalikin yang secara mendasar ditopang oleh dalil-dalil naqli berupa ayat Al-Quran dan Al-Hadits itu, apabila dicermati dari penyajian bab-babnya dimulai dari hal-hal eksoteris (lahiriyah) dalam syariat, kemudian menyentuh permasalahan- permasalahan esoteris (bathin), dan ditutup kembali melalui refeksi dalam kehidupan Muslim sebagai individu dan sebagai komponen masyarakat (terutama dalam bab VII dan Khatimah).

Mengenai paham-paham yang menyesatkan umat Islam sebagaimana yang kini tengah terjadi di negara Indonesia, kitab Thufah Al-Raghibin fi Bayan Haqiqat Iman Al-Mu'minin merupakan salah satu karyanya yang mengkaji hal ini, di dalamnya juga didapatkan tentang keburukan dari pemujaanpemujaan berlebihan terhadap tempat-tempat keramat yang bisa menyimpangkan akidah umat. Doa-doa dan wirid juga banyak terdapat dalam karya-karya Syaikh Abdus Shamad dan tak kalah pentingnya adalah aspek ketauhidan yang ditekankan untuk selalu diingat oleh segenap Muslim. Kitab Al- Palimbani lainnya seperti Siyar Al-Shalikin hampir memiliki sistematika yang sama. Dalam bab pertama Siyar Al-Shalikin ia mendiskusikan mengenai Iman dan Ibadah, bab kedua mengenai akhlak, bagian ketiga mengenai kejahatan, dan bagian terakhir mengenai berapa macam perbuatan baik yang menjauhkan pelakunya dari tindakan tercela. ${ }^{37}$

Mengenai wafatnya Syaikh Abdus Shamad Al-Palimbani, Abd.AzimAmin menye- 
but Syaikh Abdus Shamad sebagai ulama militan dan pengarang. Salah satu karyanya yakni Nasihat al-Muslimin wa Tadzkirat alMu'minin fi Fadha'il Al-Jihad fi Sabilillah wa Karamat al-Mujahidin fi Sabilillah ialah sebuah kitab yang menyerukan pentingnya jihad terhadap penetrasi bangsa Barat yang kala itu ia rasakan sendiri. Tapi ia juga menekankan pentingnya bagi umat Islam untuk berjihad melawan hawa nafsu, rasa takut mati, harus berani hidup, dan untuk memajukan agama Islam dan kemudian juga menekankan pentingnya Jihad Muthlaq yakni melawan para penentang Islam. Ia diperkirakan gugur saat melawan serangan pasukan Siam di Kuala Muda (sekarang Pattani ThailandSelatan); yang pada masa itu diduduki oleh pasukan Budhis (Siam). ${ }^{38}$ Berkaitan dengan tanggal wafatnya Syaikh Abdus Shamad, memang diakui cukup sulit, tetapi Mal An Abdullah meyakini bahwa kesyahidan Syaikh bertepatan dengan kekalahan angkatan rakyat Pattani melawan Siam pada $1832 \mathrm{M}$, di atas telah disebutkan bahwa haul Syaikh ialah pada "pada malam yang ketujuh belas daripada bulan Dzulqaidah", berdasarkan data ini, jika beliau diperhitungkan Syahid pada perang 1832, maka hari wafatnya adalah Kamis 17 Dzulqaidah $1247 \mathrm{H}$ bersamaan 19 April 1832 M. $^{39}$

\section{Kesimpulan}

Syaikh Abdus Shamad Al-Palimbani merupakan seorang tokoh Ulama Sufi intelektual yang lahir pada $1737 \mathrm{M}$ sebagaimana dijelaskan dalam manuskrip Faydh Al-Insan. Temuan baru yang diperoleh dalam manuskrip tersebut dapat membenahi kerancuan seputar nasab yang dahulunya dinisbatkan pada kitab Tarikh Salasilah Negeri Kedah. Rekonstruksi nasab tersebut sekaligus juga menunjukkan bahwa Abdus Shamad merupakan keturunan Ulama Sufi dan berdarah bangsawan. Latar belakang keluarga dan masyarakat tempatnya tumbuh, yakni Kesultanan Palembang yang sedang mengalami kemajuan di bidang keilmuan Islam. Setelah memperoleh ilmu yang cukup baik di tanah kelahirannya itu, Syaikh Abdus Shamad lalu melanjutkan pendidikannya di Haramayn, ia mengisi waktunya dengan belajar berbagai bidang keagamaan pada para Ulama. Di tengah kesibukannya menuntut ilmu, ia tidak melupakan jati dirinya sebagai orang Nusantara, dan terlibat aktif dalam Komunitas Jawi (masyarakat berbahasa Melayu di Tanah Suci).

Kepeduliannya terhadap daerah asalnya juga ditunjukkan dengan menyebarkan ilmu yang diperoleh saat pulang ke $\mathrm{Nu}-$ santara, bahkan namanya turut tercantum dalam dalam silsilah ajaran Sammaniyah di Palembang. Ilmu pengetahuan di bidang keislaman yang diperoleh Syaikh Abdus Shamad turut ia abadikan dalam sejumlah karya, dua di antaranya adalah Kitab Siyarus Shalikin dan Hidayatus Shalikin yang berbahasa Melayu, di samping sejumlah karyakarya lainnya yang seluruhnya berjumlah delapan buah. Kontribusi keilmuan tersebut tidak hanya berkaitan dalam aspek keilmuan murni, ia juga memberikan perhatian besar terhadap kondisi umat Islam di Nusantara yang tengah menghadapi ancaman penjajahan Barat dengan menuliskan sebuah karya bertema Jihad. Sekalipun Syaikh Abdus Shamad banyak berkiprah dalam bidang intelektual Islam, ia tidak melupakan pentingnya bertindak secara 'amaliyah, demikian itu ia tunjukkan dengan ikut membantu bangsa Pattani melawan pasukan Siam, hingga lalu turut gugur dalam pertempuran pada tahun $1832 \mathrm{M}$.

\section{Referensi}

Buku :

Abdullah, Hawash, Perkembangan Ilmu Tasawuf $\mathcal{E}$ Tokoh-Tokohnya di Nusantara, Surabaya: Al-Ikhlas, 1980.

Abdullah, Mal An, Syaikh Abdus Samad AlPalimbani: Biografi dan Warisan Keilmuan, Yogyakarta: Pustaka Pesantren, 2015.

Amin, Abd. Azim, Syaikh Muhammad Azhari 
Al-Falimbani: Ulama Panutan Abad Ke-19 di Nusantara, Palembang :Rafah Press, 2009. Arifin, Miftah, Sufi Nusantara : Biografi, Karya Intelektual, dan Pemikiran Tasawuf, Jogjakarta: Ar-Ruzz Media, 2012.

Bruinessen, Martin Van, Kitab Kuning, Pesantren, dan Tarekat, Bandung: Mizan, 1990.

Gadjahnata, K.H.O., Sri Edi Swasono (Ed.), Beberapa Aspek Perkembangan Islam di Sumatera Selatan, Penerbit Universitas Indonesia : UI Press, 1986.

Al-Kurani, Ibrahim, Oman Fathurrahman (Ed.), Ithaf Al-Dhaki: Tafsir Wahdatul Wujud bagi Muslim Nusantara, Bandung: PT. Mizan Publika, 2012.

Al-Palimbani, Syaikh Abdus Shamad, Kms. H. Andi Syarifuddin (Ed.), Hidayatus Shalikin, Surabaya: Pustaka Hikmah Persada, 2013.

Al-Palimbani, Syaikh Muhammad Azhari, 'Aqaid Al-Iman, Palembang: Zuriat Datuk Azhari, 2014.

Panitia Pekan Pustaka Palembang, Pekan Pustaka Palembang, Palembang: Kerjasama Perpustakaan Masjid Agung Palembang, Perpustakaan Umariyah, dan Perpustakaan Al-Wasthiyyah, 2019.

Rahim, Husni, Sistem Otoritas dan Administrasi Islam, Jakarta : Logos, 1998.

Sunanto, Musyrifah, Sejarah Peradaban Islam Indonesia, Jakarta: PT. Raja Grafindo Persada, 2012.

Syarifuddin, Kms Andi, Hendra Zainuddin, 101 Ulama Sumsel Riwayat Hidup E Perjuangannya, Yogyakarta: Kerjasama Forum Pondok Pesantren Sumatera Selatan dan Penerbit Ar-Ruzz Media, 2013.

Zed, Mestika, Metode Penelitian Kepustakaan, Jakarta: Yayasan Obor Indonesia, 2008. Zulkifli, Ulama Sumatera Selatan, Palembang : Universitas Sriwijaya, 1999.

Tesis dan Makalah :

Said, Numan, Ghazali's Work and the Influences in Indonesia, Thesis M.A. Tidak Diterbitkan, Mcgill University : Institute Of Islamic Studies, 1992.

Syarifuddin, Kms Andi, "Mengenal Lebih Dekat Pendiri Masjid Agung Palembang", Makalah Dipresentasikan dalam Seminar Sehari Mengenal Lebih Dekat Sejarah Perjuan- gan Pendiri Masjid Agung Palembang dan Ulama Pencetak Al- Quran Pertama di Asia Tenggara oleh Yayasan Masjid Agung Palembang Tanggal 18 Juli 2019.

\section{Artikel dalam Antologi Ilmiah :}

Azra, Azyumardi, "Kontroversi dan Oposisi Terhadap Wahdah Al-Wujud : Wacana Sufisme di Daerah Indonesia-Melayu pada Abad 17 dan 18", dalam Safwan, A.M., Imam Ghozali, Otong Sulaiman (Ed.), Islam, Iran, dan Peradaban, Jogjakarta : Rausyan Fikr, 2012.

Azra, Azyumardi, "Jaringan Ulama”, dalam Abdullah, Taufik (Ed.), Ensiklopedi Tematis Dunia Islam Jilid V, Jakarta: Ikhtiar Baru Van Hoeve, 2002.

\section{Artikel Media Massa :}

Abdullah, Mal An, "Haul Syekh Abdus Samad Al-Palimbani", dalam Sumatera Ekspres 6 September 2014.

Nurdi, Herry, "Jejak Emas Para Ulama", dalam Sabili No. 9 Th. X 2003. Sumatera Ekspress 22 Agustus 2016

${ }^{10}$ Musyrifah Sunanto, Sejarah Peradaban Islam Indonesia, (Jakarta: PT. Raja Grafindo Persada, 2012) 231.

${ }^{11}$ Syaikh Abdus Shamad Al-Palimbani,

Kms. H. Andi Syarifuddin (Ed.), Hidayatus Shalikin, (Surabaya: Pustaka Hikmah Persada, 2013), ix.

${ }^{12}$ Mal An Abdullah, "Haul Syekh Abdus Samad Al-Palimbani", dalam Sumatera Ekspres 6 September 2014.

${ }^{13}$ Mal An Abdullah, Syaikh Abdus Samad

Al-Palimbani: Biografi dan Warisan Keilmuan, (Yogyakarta: Pustaka Pesantren, 2015), 18.

${ }^{14}$ Mal An Abdullah, Syaikh Abdus Samad

Al-Palimbani: Biografi dan Warisan Keilmuan, 15.

${ }^{15}$ Mal An Abdullah, Syaikh Abdus Samad

Al-Palimbani: Biografi dan Warisan Keilmuan, 4-5.

${ }^{1}$ Sumatera Ekspress 22 Agustus 2016

${ }^{2}$ Martin Van Bruinessen, Kitab Kuning, Pesantren, dan Tarekat, (Bandung: Mizan, 1990), 270. 
${ }^{3} Z$ Zulkifli, Ulama Sumatera Selatan, (Palembang : Universitas Sriwijaya, 1999), 41.

${ }^{4}$ Kemas Andi Syarifuddin, Hendra Zainuddin, 101 Ulama Sumsel: Riwayat Hidup \& Perjuangannya, (Yogyakarta: Kerjasama Forum Pondok Pesantrens Sumatera Selatan dan Penerbit Ar-Ruzz Media, 2013), 38.

${ }^{5}$ Panitia Pekan Pustaka Palembang, Pekan Pustaka Palembang, (Palembang: Kerjasama Perpustakaan Masjid Agung Palembang, Perpustakaan Umariyah, dan Perpustakaan AlWasthiyyah, 2019), 7.

${ }^{6} \mathrm{Kms}$. H. Andi Syarifuddin, "Mengenal Lebih Dekat Pendiri Masjid Agung Palembang", (Makalah Dipresentasikan dalam Seminar Sehari Mengenal Lebih Dekat Sejarah Perjuangan Pendiri Masjid Agung Palembang dan Ulama Pencetak Al-Quran Pertama di Asia Tenggara oleh Yayasan Masjid Agung Palembang Tanggal 18 Juli 2019), 9.

${ }^{7}$ Mestika Zed, Metode Penelitian Kepustakaan, ( Jakarta : Yayasan Obor Indonesia, 2008), 4.

${ }^{8}$ Miftah Arifin, Sufi Nusantara: Biografi, Karya Intelektual, dan Pemikiran Tasawuf, (Jogjakarta: Ar-Ruzz Media, 2012), 91.

9Azyumardi Azra, "Jaringan Ulama", dalam Abdullah, Taufik (Ed.)., Ensiklopedi Tematis Dunia Islam Jilid V, (Jakarta : Ikhtiar Baru Van Hoeve, 2002), 245.

${ }^{16}$ Kemas Andi Syarifuddin, Hendra

Zainuddin, 101 Ulama Sumsel, 38.

17Husni Rahim, Sistem Otoritas dan

Administrasi Islam, (Jakarta : Logos, 1998), 92.

${ }^{18}$ K.H.O. Gadjahnata, Sri Edi Swasono (Ed.), Beberapa Aspek Perkembangan Islam di Sumatera Selatan, (Jakarta : UI Press, 1986.), 53- 66.

${ }^{19}$ Hawash Abdullah, Perkembangan Ilmu Tasawuf \& Tokoh-Tokohnya Di Nusantara, (Surabaya: Al-Ikhlas, 1980), 86-87.

${ }^{20} \mathrm{Mal}$ An Abdullah, Syaikh Abdus Samad

Al-Palimbani : Biografi dan Warisan Keilmuan, 21.

${ }^{21}$ Syaikh Abdus Shamad Al-Palimbani, Kms. H. Andi Syarifuddin (Ed.), Hidayatus Shalikin, ix.

${ }^{22}$ Mal An Abdullah, Syaikh Abdus Samad Al-Palimbani: Biografi dan Warisan Keilmuan, 23-24.

${ }^{23}$ Musyrifah Sunanto, Sejarah Peradaban Islam Indonesia,232.
${ }^{24}$ Miftah Arifin, Sufi Nusantara : Biografi, Karya Intelektual, dan Pemikiran Tasawuf, 8890.

${ }^{25}$ Miftah Arifin, Sufi Nusantara : Biografi, Karya Intelektual, dan Pemikiran Tasawuf,92.

${ }^{26}$ Mal An Abdullah, Syaikh Abdus Samad Al-Palimbani : Biografi dan Warisan Keilmuan, 26.

${ }^{27}$ Salah satu kitab yang penting dalam arus pengetahuan keislaman di Aceh.

${ }^{28}$ Pengantar oleh A.H. Johns dalam AlKurani, Ibrahim, Oman Fathurrahman (Ed.), Ithaf Al-Dhaki: Tafsir Wahdatul Wujud bagi Muslim Nusantara, (Bandung: PT. Mizan Publika, 2012) $x$.

${ }^{29} \mathrm{Mal}$ An Abdullah, Syaikh Abdus Samad Al-Palimbani: Biografi dan Warisan Keilmuan, 26.

${ }^{30}$ Mal An Abdullah, Syaikh Abdus Samad Al-Palimbani : Biografi dan Warisan Keilmuan, 87.

${ }^{31}$ Herry Nurdi, "Jejak Emas Para Ulama", dalam Sabili No. 9 Th. X 2003.

${ }^{32} \mathrm{Mal}$ An Abdullah, Syaikh Abdus Samad AlPalimbani : Biografi dan Warisan Keilmuan, 46.

${ }^{33}$ Syaikh Muhammad Azhari Al- Palimbani, 'Aqaid Al-Iman, (Palembang: Zuriat Datuh Azhari, 2014), 38.

${ }^{34}$ Syaikh Muhammad Azhari Al- Palimbani, 'Aqaid Al-Iman, (Palembang: Zuriat Datuk Azhari, 2014), 38.

${ }^{35}$ Azyumardi Azra, "Kontroversi dan Oposisi Terhadap Wahdah Al-Wujud: Wacana Sufisme di Daerah Indonesia-Melayu pada Abad 17 dan 18", dalam A.M. Safwan, Imam Ghozali, Islam, Iran, dan Peradaban, (Jogjakarta: Rausyan Fikr, 2012), 539.

${ }^{36}$ Musyrifah Sunanto, Sejarah Peradaban Islam Indonesia, 233.

${ }^{37}$ Numan Said, Ghazali's Work and The nfluences in Indonesia, Thesis Tidak Diterbitkan, Mcgill (University: Institute Of Islamic Studies, 1992), 58.

${ }^{38} \mathrm{Abd}$. Azim Amin, Syaikh Muhammad Azhari Al-Falimbani: Ulama Panutan Abad Ke-19 di Nusantara, (Palembang :Rafah Press, 2009), 7.

${ }^{39}$ Abdullah, Mal An, Syaikh Abdus Samad AlPalimbani : Biografi dan Warisan Keilmuan, 84. 